\title{
Observations on the Administration of Parole ${ }^{*}$
}

The assumption underlying the institution of parole is that a period of guidance and supervision for persons released from prison is useful for helping offenders avoid further criminal activity. Experience has shown, however, that persons once imprisoned will probably again engage in criminal activity, and evaluation of the offender's conduct immediately following release is necessary to determine whether a further period of incarceration is appropriate. The parole system is designed to fulfill the functions of both guidance and evaluation. On the basis of three months of observing parole officers in Connecticut, ${ }^{1}$ this Note will examine how the structure of the correctional system, and the assignment of multiple functions to parole officers, limit the officers' ability to accomplish the goal of rehabilitation.

\section{The Conditions of Parole}

Conditions of parole are imposed on every parolee. ${ }^{2}$ They purport to regulate the parolee's behavior extensively, by prohibiting some activities and requiring him to obtain the permission of his officer for others. As tools for control, conditions provide the trigger for initiating revocation: while not all violations lead to revocation, parole is never revoked unless some specific condition is violated. Critics within and

* The authors wish to thank Miss Eileen Hsu for suggesting the possibility of an altemative to parole. We are also grateful to Mr. John Manson of the Connccticut Dc* partment of Corrections, and the parole officers who let us observe them at work.

Because of the nature of the observation and the need to preserve confidentiality, many conclusions in this Note can be documented only by reference to the authors' experictice.

1. The problems of observation in this setting are detailed in the otherwise utureadable A. Crcourel, The Sochal Organization of Juvenile Justice 1.18 (1968). In attempting to examine the parole system as the parole officer sees it, we have adopted the techniques of ethnomethodology, described in P. McHugh, Definive THE Siruntion (1968), Silch all approach sacrifices extensive data collection, but seeks to describe patterns of behavior and to identify the sources of those patterns in structural features of the system. This approach was selected for two reasons. First, very little sociological work of any natute exists on the parole system. An excellent recent work, $R$. EMERSON, JudGinc Delinguenis (1969), treats similar patterns in the system of juvenile probation, but the syistems differ significantly in the extent to which judges participate in the process and in the avalla ability of alternative systems of social control. In addition, probation deals only with offenders who have not served time in prison for their current offense, while all parolces have been recently released from prison. Emerson's book does, however, shed light on specific problems in parole. Second, ethnomethodological studies of deviance have centered on the life of the deviant rather than upon the instituitons which define the behavior as deviant. For a review of the literature and a significant theoretical contribution, sce $D$, Matzi, Becoming Delineuent (1969).

2. A printed form stating several general conditions is given to every parolce. Thlie Parole Board also imposes conditions tailored to certain classes of offenders, such as al. coholics and narcotics addicts, and occasionally to individual offenders. 
outside the field of corrections have argued that conditions of parole are often so broad as to be both meaningless and unenforceable. ${ }^{3}$ Many lawyers see such conditions as unbridled license for arbitrary action. Conditions prohibiting association with "undesirable" characters may, for example, be used to invoke sanctions against parolees whom more political agencies wish to punish, such as a Mafia leader against whom no evidence of crime can be found. 4

Criticism of the breadth of parole conditions has ignored the importance of these conditions in helping the parole officer fulfill his guidance functions. More important to the officer than the use for revocation is his use of conditions to gather information about the parolee. Commentators, while recognizing that the officer has discretion in defining violations, ${ }^{5}$ have failed to analyze this use of parole conditions, focusing instead on the general problem of authority in parole supervision. In practice, although conditions may not be a means of building an effective casework relationship, ${ }^{0}$ they are nevertheless an important part of parole casework. But this use of the conditions is made less effective by the existence of the threat that the officer will use the information to initiate revocation.

In their initial conversations with newly-paroled men, officers commonly confront a problem: the parolees have learned about parole through a prison communication system which obtains information almost exclusively from prisoners whose parole has been revoked. The parolee's initial expectations, then, are often shaped by "horror stories" about parole officers which have circulated in prison. A large part of the initial interview must therefore be spent trying to dispel the parolee's preconceptions-convincing him, for example, that a violation of his conditions, even an arrest for a misdemeanor, will not automatically result in revocation of his parole. In reviewing the conditions,

3. See, e.g., R. Dawson, Sentencing 306-07 (1969); Note, Judicial Retiew of Probation Conditions, 67 Colum. L. REv. 181 (1967); Comment, Conditions of Probation Imposed on Wisconsin Felons, 1962 WLs. L. REv. 672; Best \& Birzon, Conditions of Probation: An Analysis, 51 Geo. L.J. 809 (1963); VonHentig, Degrees of Parole Violation and Graded Remedial Measures, 39 J. Crmr. L. \&: C. 363, 365 (1943); Bates, On the Uses of Parole Restrictions, 33 J. CRn. L. \& C. 435 (1943). See also Note, Frcedom and Rehabilitation in Parole Revocation Proceedings, 72 YALE L.J. 368, 378 (1962).

4. The EIdridge Cleaver case is another illustration of how political pressure can lead to revocation of parole. In re Cleaver, 72 Cal. Rptr. 20 (Ist Div. 1968); E. Cletven, POstPrison WRTINGS AND Speeches (1969).

5. See Bates, supra note 3, at 438; DiCerbo, When Should Probation Be Revoled, 30 FED. Prob. 11, 12 (June 1966); Hendrick, Basic Conceptions of Conditions and Vialations, 2 N.P.P.A.J. 1, 3 (1956).

6. See Wallace, The Casework Approach to Rules, 2 N.P.P.A.J. 14, 19 (1950).

7. Cf. Skolnick, Toward a Development Theory of Parole, 25 Au. Soc. REv. 542, 543-44 (1960). Many offenders, of course, have leamed of parole through prior experiencewhich may have ended in revocation. 
the officer emphasizes not the pervasive control they authorize but the minimal extent to which they will be used to restrain the parolee's freedom of action. ${ }^{8}$

At the same time, officers stress that the parolee must inform his officer of any violations. The conditions provide that the officer must be informed whenever the parolee contemplates an important change in his life: a switch of residence, a new job, an impending marriage, at1 intention to purchase a car. Failure to inform the officer never leads to revocation, though it often elicits a reprimand. Officers use the con* ditions not as tools to control the parolee's behavior, but as devices to legitimize their inquiries into areas of the parolee's life which bear on his rehabilitation. As such, conditions are a tool for casework. But because of the parolee's ineradicable fear that violation may lead to a return to prison, the parolee is never fully candid. He gives some in. formation, retreats, hedges, and must be coaxed into telling a straight story. The officers, recognizing this reluctance, probe cautiously and support the parolee, often by indicating that the officer's intercession with other agencies will help the parolee.

To further a helping relationship with the parolee, the officer must of course elicit information from him. The use of parole conditions to compel disclosure of this information is not, however, necessary for effective casework: once a parolee trusts the officer and sees him as an advocate, information will flow willingly. Eliminating the fear that information will be used as a basis for revocation will facilitate a relationship of trust, and a full and free flow of information will enable the parole officer to be more effective in his guidance function.

\section{The Parole Officer As Social Worker}

The parole officer functions in much the same way as a social worker. $\mathrm{He}$ is instrumental in channeling the parolee to specialized social agencies such as psychiatric clinics and Halfway Houses. The officer attempts to find every parolee an adequate job by developing contacts and cultivating local businessmen. Routinely the officer intercedes with the Motor Vehicles Bureau to restore the parolee's license. When marital difficulties arise, the officer does some counseling, then guides the parolee to a family service agency.

Like all social workers, the parole officer is limited by society's

8. Cf. Wallace, supra note 6 , at 17-18. 
failure to provide resources adequate to deal with the client's problems. Many institutions which might help the parolee are overburdened or ineffective. Moreover, some are hostile to narcotics addicts, a significant proportion of the urban officer's caseload, because addicts are believed not to benefit from the agencies' services. ${ }^{.}$Similarly, the officer may be limited by the lack of available jobs. Employers who do hire parolees are frequently friendly and eager to help, but even they cannot provide jobs in a depressed market. Within such limits, however, parole officers act as intermediaries between the parolee and social institutions with which he has lost contact while in prison.

Though hindered by reliance on parole conditions in eliciting information about parolees' problems, and despite a lack of formal training for the task, parole officers attempt to counsel parolees on personal problems which affect their success in readjusting to life outside prison. This guidance is often superficial, but little blame can be attached to the officer. Each parole officer sets aside one evening a week to receive parolees on their required monthly visits. The information received by the officer in these interviews is often pursued later in the week, when he calls on other agencies with which the parolee has had contact. During much of his working day, the officer works closely with a limited number of parolees whose problems put them in imminent danger of returning to prison. But with a caseload of more than sixty, ${ }^{10}$ the officer cannot spend much time in probing and inducing the parolee to disclose more than the parolee volunteers.

While direct counseling is somewhat limited by the time available, it is even more constrained by the officer's doubts about the legitimacy of his intervention. The officer believes that, since his "services" are thrust upon the parolee, he cannot make his counsel too aggressive. Guidance which appears to the parolee as control rather than advice is regarded not only as an intrusion upon the parolee's privacy not justified by consent, but as counterproductive in that it may bring out a submerged fear of revocation. Counsel is therefore presented as gentle suggestion which is often misunderstood by the parolee.

9. Parole officers and other social agencies accept what Glazer calls "the myth that two-thirds return," at least as it applies to narcotics addicts. See D. Glazer, TuE Erractiveness of a Prison and PARole SYstenr ch. 1 (1964).

10. Caseloads in Connecticut average around 65 to 70. Effective supervision is said to require caseloads of no more than 35. Presidenr's Cosmission on LAW Enforicesrast AND THE ADMINISTRATION OF JUSTICE, TASK FORCE REPORT: CORRECTIONS 4, 70 (1967). Compare $\mathbf{R}$. Dawson, supra note 3 , at 332-33 (caseloads in Kansas 200, in Detroit 100, in Milwaukee 55). 


\section{Bureaucracy and Professionalism}

The parole officer sees himself as a professional in social work and corrections, but his job places him in a bureaucracyl1 whose need for control often conflicts with the professional's desire for autonomy. In a recent reorganization of the Connecticut corrections system, the parole office was separated from the Board of Parole and placed within the Department of Gorrections. The Parole Board's responsibility ends, barring a violation of parole, when parole is granted. The parole officers are located in three field offices, each of which is headed by an area supervisor. Besides his social work functions in guiding and being consulted by the officers, the area supervisor coordinates the operation of the field office and serves as its liaison to the Board of Parole and the Department of Corrections. In each office there are several field officers who work directly with parolees. Except for an institutional parole officer who develops parole plans and orientation for prisoners about to be released on parole, no other officer specializes in a particular type of offender; each officer is responsible for all parolees released to residences within a defined geographical area. ${ }^{12}$

The parole officer's claim to professionalism rests upon his kinship to the social worker. Many definitions of "profession" have been advanced..$^{13}$ Here it is enough to say that a professional is certified by an agency other than the employer, and applies systematic knowledge acquired through prescribed training. Though the knowledge involved need not be scientific, it must be systematic. Legal doctrines, for example, form a coherent body of knowledge which is not "scientific." In addition, professionals adhere to norms defined by their own organizations; they see themselves as autonomous from their employers and accountable only to their colleagues for validation of their professional conduct. The most important professional norm is the service ideal: professionals are obligated to supply help to all those in need of their special expertise.

As a profession, social work involves knowledge of human motivation and social institutions, and the application of that knowledge to the problems clients present. The professional norm of objectivity is particularly hard to maintain since the helping relationship requires

11. For a classic description of the characteristics of a bureaucracy, see M. Wrorr, Bureaucracy, in FROM MAX WEBER 196, 196-98 (1946).

12. In Hartford, because of the large number of youthful offenders on parole, two officers work only with young offenders while two others handle older parolecs.

13. Wilensky, The Professionalization of Everyone?, 70 A.4. J. Soc. 137, 138.40 (1964). 
emotional involvement. Objectivity is preserved by the social worker's experience with similar problems and awareness of the limitations within which they must be met. ${ }^{14}$ As WVilensky and Lebeaux have written:

[C] ]asework is a type of counselling process which emphasizes helping an individual to identify, clarify, and understand his own - difficulties to the point where he can free himself from them, or accept help.

. . . Casework operates on the premise that any individual fac. ing social stresses which he cannot deal with has strengths and inner resources which, if freed from the shackles of fear, inhibition, and other types of psychological blockage, will enable him to become effectively self-responsible. . . . Casework's motto is "help people to help themselves.". . Exhortation and coercion are avoided. ${ }^{15}$

The parole officer's claim to professionalism is that he does casework, and his professional norms are those of the social worker, not the policeman. Though there are few standard requirements for becoming a parole officer, many have had social work training, ${ }^{10}$ and all feel and exhibit a trained sensitivity to the problems of parolees.

Bureaucratic pressures constrain the parole officer's sense of professionalism.17 Officers feel that red tape is an insult to their professional status. Some officers object to the forms they are required to fill out; instead of submitting a simple list of supervisory contacts at year's end, they would prefer to make short substantive summaries of the year's events. Professional status is further undermined by the control exercised by non-professionals in the Department and on the Parole Board.

Under the Connecticut parole system, however, whatever frictions are generated by placing professionals in a bureaucracy are muted. The upper echelons do not closely regulate the field officer. The area super-

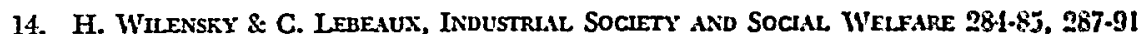
(1958). For a general discussion of the professional aspects of socinl work, see Toren,

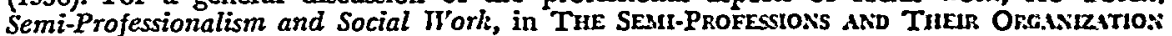
141 (A. Etzioni ed. 1969).

15. TVilensky \& Lebeaux, supra note 14 , at 290.

16. The Department requires a college degree and one year of field experience for a beginning officer. Seventy per cent of the officers in Connecticut had adrance training and field experience in social work, while the remainder had police experience. Compare Gross, Biographical Characteristics of Juvenile Probation Officers, 12 CRME \& DEL. 109, 111 (1966) (67\% of sample had bachelor's degrees; $23 \%$ had master's degrees).

17. A. BluMiberg, Criminal Justice 156 (1967): "The greatest source of dissonance in probation officers' work lives is the tenuous and unrealistic nature of their asserted professionalism." Blumberg's polemic may be true of probation officers, but it is not true of parole officers, whose claims to professionalism have a solid foundation in their work. 
visors view their jobs in professional, not bureaucratic terms. The parole officer sees himself only loosely bound by rules which purport to regulate his work; for example, the officer does not feel obliged to report every violation of parole conditions. Even when routinized modes of behavior are adopted, as when the initial interview takes a standard shape or when routine procedures are used to get the parolee a job, they are dictated more by the pressures of time than by rules from above.

Other structural features on the job reinforce an officer in his attempt to do casework. The Department of Corrections encourages officers to take courses in sociology and social work by subsidizing their tuition. Supervisors encourage casework and support officers faced with difficult decisions. Nearly every decision to recommend revocation of parole is discussed extensively, if often informally, with the supervisor. ${ }^{18}$ The office is run informally; each officer has nearly complete discretion to order his time as he wishes. Perhaps most important, the officer's work cannot be tightly regulated. Most of his work involves private interactions with and on behalf of the parolee. The quality of the service he provides cannot be evaluated by simple statistics, but must be judged by less concrete standards. ${ }^{10}$ As a result, the parole office resembles not a company's accounting department but a partnership of professionals, each autonomous in his realm.

\section{The Threat of Role Conflict}

The parole officer's authority to invoke sanctions creates conflicts not only with the parolee but also within himself, by forcing him to choose between the goals of rehabilitation and control. Instead of attempting to reconcile these incompatibles, the parole officer unequivocally pursues the former, choosing to be a social worker rather than an adjunct of the police.

Parole officers must go to police headquarters frequently, since parolees are constantly being picked up..$^{20}$ Here and at the prison the parole officer talks with men of a different orientation who also have

18. Cf. Hendrick, supra note 5, at 3. See also Carrera, Some Thoughts on the Probdtion Supervisor's Job, 32 FED. ProB. 28 (Sept. 1968).

19. Compare P. Blau, The DYNamics OF Bureaucracy 34.40, 102 (1955) (contrasting measurement of productivity through statistics and through professional judgment).

20. Indeed, some parole "offices," particularly those in rural areas used only once a month for interviews, are located in police stations. 
daily contacts with parolees, prisoners, and criminals. And like policemen, urban parole officers develop extensive contacts in the criminal subculture. They take part in the informal criminal communication system to learn what is happening, who is doing it, and why. Information is given by these contacts with the joint understanding that it is not to be used punitively but rather for insight into the parolee's life, to keep him away from activities that will lead to a return to prison.

Observation revealed a striking absence of police ideology among parole officers. For example, revocation was recommended only after a series of events which indicated to the officer that the parolee would not benefit from continued parole. This lack of a punitive orientation is particularly remarkable given the attention paid to the conflict between custodial and treatment goals in the sociology of corrections.21 Whereas prior studies have concentrated on conflicts between different types of workers, ${ }^{22}$ in parole both goals are part of the officer's orientation. His rejection of one of these goals must be explained.

In sociological terms, the problem is one of role conflict. Role is defined as "a set of expectations, ... . a set of evaluative standards applied to an incumbent of a particular position."23 Here the incumbent, the parole officer, faces expectations from several "counter-positions" - the Department of Corrections, parolees, the police, and the public. Most of these "counter-positions" generate expectations consonant with professional norms. The Department of Corrections shares and reinforces the parole officer's rehabilitative orientation. Promotion of officers with field experience to supervisor, for example, comports with social work ideology, in which supervisors should be sensitive to the problems faced by men in the field. The social agencies and employers whom the officer contacts also view the parole officer as a social worker.

Others, however, expect parole officers to be like policemen. Parolees often cast their officers in this role. But since the parole officer sees these expectations as based on a misconception of his purpose, the ex-

21. See, e.g., Weber, Conflicts Between Professional and Non-Professional Personnel in Institutional Delinquency Treatment, 48 J. CRm. L.C. \& P.S. 26 (1957); Hall, VWilliams \& Tomano, The Challenge of Correctional Change, 57 J. Crms. L.C. \& P.S. 493, 494 (1960); Grusky, Role Conflict in Organization, 3 AD. Scr. Q. 452, 453 (1959); Cressey, Conlradiclory Directives in Complex Organizations, 4 AD. ScI. Q. 1 (1959).

22. But see Grusky, supra note 21, at $456-59$.

23. N. GRoss, W. MASON \& A. MCEACHERN, Exploritions In ROLE ANALYsis 60 (1958). This work is a brilliant model of definition and analysis; unhappily, it is more cited than imitated. For a lucid and incisive critique, see R. DAHRENDonf, Homo Sociologicus, in ESSAYS IN THE THEORY OF SOCIETY 44 (1968).

24. N. Gross et al., supra note 23 , at 62. 
pectations cannot define how he ought to behave; they are simply obstacles to be overcome. The police themselves, however, view the parole officer as an ally. Parole revocation is used as an alternative to prosecution for serious offenses, and is seen as an easier method for reincarceration of the offender. ${ }^{25}$ However, the police have few sanctions with which to enforce their expectations by shaping officers' conduct. A parole officer who did not recommend revocation in some cases where the evidence "warranted" it might lose some police sources of information, but his work would suffer minimally because he has many other sources. Finally, the "public" expects parole officers to be law enforcers. But this expectation is mediated through the officer's friends, who are likely to be more sympathetic to his non-punitive ap. proach than the general public. Thus, conflicting expectations do exist, but the parole officer interacts far more with professionals who accept his own orientation than with people who expect him to perform police functions. The norm of service is reinforced while that of punishment lacks support. ${ }^{26}$

The self-selection of parole officers also diminishes role conflict. No formal tests measure the officer's professional orientation, but the first months on the job serve to screen out overly punitive officers. More important, as one officer said, "You have to be an optimist to take this job." In part, optimism is ensured by the requirement that parole officers have social welfare or law enforcement experience. Men who choose to leave law enforcement positions may have had their optimism stifled in the police agency. Perhaps too their experience has shown them how human it is to become a criminal. On the other hand, while social workers are assumed to be "optimists," their move to parole may indicate a more punitive orientation. For example, most officers felt the practice of carrying weapons unnecessary and demeaning to their professional status; the officers who wanted weapons had all been welfare workers.

Role conflict, then, seems to have only a small impact on the officer. The system hires and promotes men whose values are those of the social worker, and once they assume the role, officers are in contact largely with groups which reinforce those values.

25. See R. Dawson, supra note 3 , at $340.41,358,363$.

26. This argument is consistent with the empirical findings of N. Gross et al, supra note 23. Interaction increases role consensus, $i d$. at 177; homogeneous preparation (loes the same, id. at 146; membership in a profession limits consensus with non-profcssionals, id. at 180-81; and the legitimacy of expectations is a key dimension in resolving role conflicts, id. at $285-86$. 


\section{Authority and Social Casework}

The casework process in parole is distorted at nearly every point by the fact that the parole officer is authorized by the state, not by the parolee, to invoke penal sanctions against the parolee. Parole officers must accommodate themselves to a situation in which they have power to which social work ideology denies legitimacy, that is, where the client's participation in the relationship is compelled rather than voluntary.

Casework theorists have not dealt with the problems of authority faced by parole officers. Instead of modifying casework theory to take account of authority, theorists blur the meaning of authority to bring it into accord with casework theory. Some, indeed, dismiss the problem by exhorting the parole officer to be a superior social worker so that the wall of authority can be broken down. ${ }^{27}$ But the most common response is to assert that authority can be a positive tool in rehabilitative work. Authority is said to be a universal factor with which the parolee must learn to live; ${ }^{28}$ the officer's authority is a pole of stability which helps the parolee orient himself. ${ }^{29}$ While these general propositions may be true, ${ }^{30}$ they miss the point by failing to distinguish among types of authority. A loving, parental authority, the model on which these theorists rely, is fundamentally different from a policeman's legal authority.

In psychological terms the availability of sanctions transforms the parole officer from one who suports the client's ego to one who sits as super-ego on the parolee's shoulder. There is no assurance that this super-ego control will be internalized, for unlike the family model, there is no reason to expect that the authority will be seen as loving. In a family model of the officer-client relationship where the officer takes the parent's role, the relationship becomes strained. The officer

27. See, e.g., id. at 247, 273-74; Weiss, The Social Worker's Technique and Probation, in Probation and Criminal Justice 165, $184-86$ (S. Glueck ed. 1933); Mecher, Probation is Casework, 12 Fen. Prob. 51 (June 1948); Studt, An Outlinc for the Study' of Social Authority Factors in Casework, in SOcIAL CuSEwORK IN TIE FIFtres 272, 275 (C. Kasius ed. 1962).

28. See, e.g., Tracey, A Social Worker's Perspective on Social Worl in Probation, 7 CRIME \& DEL. I3I, 134 (1961); Hardman, Authority in Caseworl, 5 N.P.P.A.J. 249 (1959); D. Dressler, Practice and Theory of Probation and Parole 139 (1959).

29. See, e.g., Hardman, The Constructive Use of Authority, 6 CRnIF. \& DEt. 245, 250 (1960); Kawin, Therapeutic Use of Authority, 17 FED. Pros. 22, 24 (Sept. 19j3); Sharif, Authority in the Client-Worker Relationship, 17 FED. Prop. 22, 24-25 (June 1953); Silverman, Surveillance, Treatment, and Casework Supervision, 2 N.P.P.A.J. 22, 23 (1950).

30. For contrasting views, compare Studt, Casework in the Correctional Ficld, 18 Feo. Prob. 19 (Sept. 1954), with Blake, Probation Is Not Casez'ork, 12 Fed. Pros. 54 (June 1948). For an argument that the discussion is misdirected, see Kelling, Caught in a Cross. Fire of Concepts, 14 CrIME \& DEL. 26 (1968). 
resents the lack of reciprocity, though he understands its origin and indeed believes it to be reasonable. The parolee resents the officer's forced intrusion into the parolee's "family," and the relationship, despite the officer's efforts to help the parolee adjust to a hostile world, rarely transcends the parolee's initial suspicion. That it does so on occasion indicates how well some officers do their job. But they too find it anomalous to assume a parental role in relation to a grown man, which may account for some officers' discouragement with their work with older offenders.

In addition, the officers really do not want to force their services on anyone. They do not search out problems, and they hesitate to probe deeply into the parolee's life through use of the conditions of parole. Their concern for the legitimacy of intervention stems from the consensual norms of social work. The lack of consent and the availability of sanctions put the officer who wishes to do social work under strain from the conflict between his ideals and his position.

That strain is only slightly relieved by other structural elemeñts; success in overcoming the conflict depends far more on the officer's talent. Recruitment and promotion practices, by reinforcing social work norms, only exacerbate the problem, which lies precisely in the officer's adherence to social work norms in a setting where they cannot be fully realized. The legal requirement that parole can be revoked only for some violation of a specific condition ${ }^{31}$ suggests that the system places great value on the maximization of freedom. ${ }^{32}$ It also serves the rehabilitative goal by limiting the officer's discretion, thereby making it easier for the parolee to trust the officer, and by letting the officer believe that the parolee's objective behavior and not the officer's professional judgment is responsible. when parole is revoked. ${ }^{93}$ But this is a pallid technique of evasion; the problem can be removed only by giving the authority to initiate revocation to other officials. ${ }^{34}$

Parole officers have developed other ways of reducing tension. Social work theory provides a definition of successful casework: the establishment of a helping relationship. ${ }^{35}$ Instead of adopting this definition, however, officers use a more result-oriented approach, in which they

31. R. Dawson, supra note 3 , at $\$ 40-41$.

32. Note, Freedom and Rehabilitation in Parole Revocation Hearings, 72 YALE L.J. 368,378 (1962).

33. Cf. A. Gouldner, Patterns of Industrial Bureaucracy 164-66 (1954) (screcning function of rules).

34. For a similar argument, see R. EMERSON, JUdGING DELINQUENTS 230-35 (1969).

35. See, e.g., G. Hamilton, Theory and Practice of Social Casework v, 6, 22, and passim. 
concentrate on the ultimate fate of the parolee. Success is defined as (1) seeing a parolee through to his discharge from parole, or (2) keeping him out of prison longer than he would have stayed out without the officer's supervision. Because of the Parole Board's new release policy, under which nearly three-quarters of the applicants receive parole on the date they are first eligible, ${ }^{36}$ some officers believe that the Board no longer screens applicants with an eye to their likely success on parole. This practice relieves some tensions when the goal of discharge is adopted. Most of an officer's time is spent with parolees whose successful discharge is unlikely, but the officer can blame the Board for failing to screen out prisoners whose early release was ill-advised.

Though it is sometimes difficult to tell how long an unsupervised parolee would have remained out of prison, the second definition of success helps reinforce the officer's professionalism. His sense of success is determined in part by comparing the experience of other officers with offenders of a similar type. Officers discuss past parolees constantly, and each new case reminds them of old ones. These discussions and exchanges of information among officers are valuable not only in reinforcing a sense of professionalism, but also in allowing officers to review and reflect upon their own experiences in the company of a sympathetic audience.

Though a definition of success in terms of keeping a parolee out of prison creates its own problems, it provides officers with a way of evaluating their own performance without reference to the impracticable social work standard. It serves therefore to divert the officers from some of the tensions created by the contrast between the reality of the job and the ideals to which they adhere.

\section{Conclusion}

So long as authority to invoke serious sanctions lies in the hands of parole officers, demands to circumscribe that authority will inevitably arise. Most commonly, the demand is for procedural protections for the parolee. ${ }^{37}$ This approach fails, however, to deal with parole as it is

36. N.Y. Times, Jan. 15, 1970, at 47, col. 2. In practice, all states must release almost all prisoners before the expiration of their terms, simply to make room for new inuates. The TASK FORCE REPORT, supra note 10, at 194, states that the arerage daily parole cast per case is 88 cents, while the average daily prison cost per prisoner is \$5 $\$ 4$. Compare Comment, Due Process and Revocation of Conditional Liberty, 12 WAviv I. REv. 638, 610 (1966): "The primary consideration underlying parole is probably cconomics."

37. See, e.g., Kadish, The Advocate and the Expert: Counsel in the Pcno-Correctional Process, 45 MinN. L. Rev. 803 (1961); F. CoHEN, LEG.A. Nonnis in CorRrctions (1967); A. Blumberg, supra note 17; Note, Parole, 38 N.Y.U.L. REv. 702 (1963); Note, Freedom and 
actually administered. Such arguments address a conception of the parole process in which officials exercise an uncontrolled discretion, whereas the actual use of authority by parole officers is directed to and limited by the professional ideal of rehabilitation. Imposing procedural protections cannot help officers achieve this goal.

An outline of a more drastic revision of the parole system can highlight the relationships between authority, rehabilitation, and control. The changes proposed here are not intended as recommendations, but rather as suggestions about the paths which less comprehensive changes might take if parole is to become an effective means of rehabilitation.

If parole officers were deprived of their authority to invoke sanctions, most of the structural obstacles to rehabilitation vould disappear. The officers could then pursue more effectively the rehabilitation work they wish to do. Parole revocation could become more judicial, for those who would revoke parole-the Parole Board-would function as decisionmakers in an adversary process. Parole officers would represent the state's interest in rehabilitation and the prosecutor and police its interest in deterrence, while the parolee and his lawyer would advocate the parolee's interest.

The alternative system could be instituted without eliminating the functions of parole. Because the parole system would no longer provide penal sanctions, the parole office would become a specialized social agency devoted to the needs of just-released prisoners. It would, of course, provide some rewards, such as job placement and easier access to other agencies, for those parolees who chose to use it. But no parolee would be compelled to report to the parole office; if he came, he would come because he believed the office was designed to help him..38 Extensive preparation before release would inform prisoners of the help the parole office could give them, but the ultimate decision to use the office would be the parolee's. The parolee's voluntary approach would, in turn, establish the basis for guidance legitimized by the parolee's consent.

In such a system, the police and not the parole officer would invoke the process of summary revocation. If a parolee had used the parole office, it would be informed, and the parole officer would consult with

Rehabilitation in Parole Revocation Hearings, 72 YALE L.J. 368 (1962); Note, 1969 DuKL L.J. 139; Comment, Due Process and Conditional Liberty, 12 WAYNE L. REV. 698 (1966); Comment, 28 S. CaL. L. REv. 158 (1955); Note, Parole Revocation Procedures, 65 Harv. L. REv. 309 (1951); Hyser v. Reed, 318 F.2d 225, 249.52 (D.C. Cir. 1963) (Bazelon, J., dissenting).

38. Cf. Ohlin, Piven \& Pappenfort, Major Dilemmas of the Social Worker in Prabation and Parole, 2 N.P.P.A.J. 211, 215-16 (1956). 
the police and the parolee. At this point, complex issues of confidentiality arise. An absolute privilege for officer-client communications may be necessary to preserve open communication. Even with such a privilege, however, the parole officer may feel a strain between his professional duty to his client and his citizen's duty to the police, as when a parolee tells the officer of a crime the parolee has committed. But such strains inhere in all professions and are resolved by the canons of professional ethics.

Without the risk that the parole officer will invoke penal sanctions, his professional judgment can be trusted during the period of supervision. Vesting the actual responsibility for revoking parole in the Parole Board would bring the revocation process closer to the due process model and, though limiting the parole officer's responsibility, would not diminish his sense of professionalism. The American legal system assumes that lawyers are better able to balance competing considerations of public policy than are other professionals. By assigning single functions to institutions like parole, the legal system would ensure that the balancing be done openly by officials expected to have special abilities.

Any analysis of the operation of parole and of proposals for change must recognize the dual nature of parole. It is a mechanism of control, but it is also an attempt, sincerely and ably implemented, to guide convicted offenders into socially accepted ways of living. Criticism of the parole system, by focusing only on the first purpose, generates understandable resentment from parole officers. Neither an increase in the officers' authority nor a circumscription of that authority by procedural protections can advance the goal of rehabilitation. Criticism of parole is best directed toward those aspects of the system which inhibit rehabilitation. The guidance function of parole officers may best be strengthened by eliminating entirely their authority to invoke sanctions. 